\title{
SPEECH PROSODIC PORTRAIT OF AMERICANS OF VATIOUS AGES
}

\section{МОВНИЙ ПРОСОДИЧНИЙ ПОРТРЕТ АМЕРИКАНЦІВ РІЗНОГО ВІКУ}

\section{Nataliia Koval ${ }^{1}$}

DOI: https://doi.org/10.30525/978-9934-26-001-8-1-12

Abstract. The present study is an experimental phonetic analysis of the Americans' prosodic characteristics depending on different ages, the experimental part of which is devoted to consideration of melodic peculiarities of American speech. The research topic is determined by the fact that the influence of personally related factors, namely the age of a person, on the process of speech production hasn't received a sufficiently complete consideration during previous studies, since it did not constitute a subject of special studying. This research correlates with sociophonetics, which studies phonetic characteristics of human speech behavior in various social groups and social situations. The choice of the American variant of the English language as the research material is explained by the greatest prevalence of this variant in the world community. The aim of the study is to identify the most frequent melodic configurations and temporal features of Americans' speech representing four age groups (adolescence, youth, maturity, old age), as well as in determining the internal relationship between the prosody of sounding speech and the main stages of personality's development and socialization. The subject of the study can be defined as the dynamics of change melodic and temporal design of Americans' speech in depending on the age of the speaker. A comprehensive research method combining a theoretical-analytical method, an audit, a comparative method and a method for correlating data obtained during the experiment, as well as their linguistic interpretation, is applied in the work in full. The main conclusion of our study is the confirmation of the fact that for each age

${ }^{1}$ Candidate of Sciences in Philology, Associate Professor of the Department of Foreign Languages for Humanities Faculties, Odesa I.I. Mechnikov National University, Ukraine 
there is its own specificity of prosodic formulation of an utterance, which is expressed in a certain set of melodic features typical for the speech of representatives of a particular age group. We can state that the dynamics of prosodic changes in a person's speech throughout his life does indeed take place, and it is due to biological, psychological and social factors. Human personality is a complex unity of the above-mentioned components, which are in a constant interaction and have a direct impact on the individual's speech behavior. Consequently, the study of the process of speech production and the identification of its specifics at a certain stage of a person's life is possible only with an integrated approach to the study of personality, taking into account all the variety of factors affecting it.

\section{1. Ветуп}

Це дослідження є фонетичним аналізом просодичних характеристик мови американців різного віку, експериментальна частина якого присвячена розгляду особливостей мелодики американської мови. Під просодією автор дослідження розуміє фонетичні супрасегментні характеристики мови як на рівні сприйняття (висота тону, гучність, тривалість), так і на фізичному рівні (ЧОТ, інтенсивність, час). У цьому значенні просодія протиставлена інтонації, яка позначає функціональні категорії [5, с. 401].

У сучасній лінгвістиці існує велика кількість визначень просодії, значна частина яких, однак, зводиться до того, що «термін «просодія» використовується в супрасегментної фонетиці та фонології для позначення змін висоти тону, гучності, темпу і ритму» [15, с. 289]. Просодія, за визначенням Р.К. Потапової, є система фонетичних засобів (висотних, силових, тимчасових), що реалізуються в мові на всіх мовних рівнях. Вищевказані фонетичні засоби відповідають основним фізичним характеристикам: частоті основного тону, інтенсивності та тривалості [10]. Актуальність теми визначається тим, що виявлення зв'язку просодичного оформлення синтагми з віковими характеристиками мовця $\epsilon$ необхідною умовою не тільки для більш повного та глибокого вивчення процесу оволодіння рідною мовою, а й для розвитку особистісно орієнтованого підходу до навчання іноземної мови. В даний час провідну роль в навчальному процесі відіграє особистість студента. Отже, тільки з урахуванням специфіки впливу особистісних факторів 
на фонетичну сторону мови студентів, i, зокрема, на реалізацію мелодійного і темпорального компонентів просодії, навчальний процес може вважатися комплексним та повноцінним.

Мета дослідження полягає у виявленні найбільш частотних мелодійних конфігурацій мови американців, які представляють чотири вікові групи (юність, молодість, зрілість, похилий вік), а також у визначенні внутрішнього взаємозв'язку між просодією усної мови та основними етапами розвитку та соціалізації особистості. Відповідно до мети роботи авторкою були поставлені наступні завдання: проведення аудиторського аналізу мелодійних особливостей непідготовленого монологічного мовлення американців різного віку; визначення основних закономірностей і тенденцій у виборі просодичних моделей в залежності від віку мовця та виявлення зв'язку просодії з основними етапами розвитку особистості. Об'єктом дослідження є мелодійні характеристики непідготовленого монологічного мовлення жителів США різних вікових груп. Предмет дослідження можна визначити як динаміку зміни мелодійного оформлення мові американців в залежності від віку мовця.

Основним матеріалом дослідження слугували мультимедійні програми, а також аудіо- та відеозаписи мови жителів США різних вікових груп, зроблені в навчальних цілях та які становлять лінгафонні курси 3 навчання американському варіанту англійської мови. Інформанти це чоловіки та жінки, зайняті в різних сферах діяльності та які проживають в різних регіонах США від південного сходу і сходу (штати Джорджія, Коннектикут, Нью-Йорк, місто Нью-Йорк) до північного заходу і заходу (штати Вашингтон, Каліфорнія, Орегон), включаючи центральну частину (штат Канзас). Корпус дослідження представлений 30 уривками промови інформантів. Отже, корпус дослідження склав 30 хвилин звучання. Вікова класифікація інформантів заснована на класифікації Н.Н. Палагіної [7], згідно з якою протягом життя людина проходить наступні етапи: 1) юність (17-25 років); 2) молодість (25-35 років); 3) зрілість (35-55 / 60 років); 4) похилий вік (60-80 років).

Корпус матеріалу для проведення аудиторського аналізу склали 30 уривків непідготовленого монологічного мовлення американців побутового характеру, кожен тривалістю звучання приблизно 60 секунд, що представляють собою відповіді на запитання під час 
інтерв'ю з наступної тематики: сім'я, робота, захоплення, плани на майбутнє і т.д. Необхідно відмітити, що експериментальний матеріал повністю $є$ автентичним та ретельно відібраний авторкою дослідження з мультимедійних програм, аудіо- і відеокурсів, заснованих на справжніх інтерв'ю з носіями англійської мови з США. Важливо і те, що під час запису інтерв'ю всі учасники експерименту перебували в подібній ситуації спілкування: неформальна обстановка, відсутність численної аудиторії, неофіційна бесіда з інтерв' юером, типові питання побутового характеру - все це, безсумнівно, чинило позитивний вплив на емоційний стан мовця.

\section{2. Аудиторський аналіз}

В ході проведення аудиторського аналізу, де в ролі аудитора виступав автор цього дослідження, була вивчена специфіка мелодійного оформлення усної фрази, іiї сегментація та паузація. Відповідно до традицій британської лінгвістичної школи, прийнято розподіл мелодійного контуру синтагми на два елементи: шкала (пред’ядерна / предтермінальна частина) та термінальний тон (ядерна / термінальна частина). В ході аналізу предтермінальної частини висловлювання, шкали класифікувалися за такими параметрами: рівень початку шкали (реєстр): 1) високий; 2) середній; 3) низький.

Тип шкали за характером зміни мелодики: 1) однонаголошена; 2) спадна (ступінчаста, зі спеціальним підйомом, змінна, скандентна, хвилеподібна); 3 ) висхідна (ступінчаста); 4) рівна; 5) змішана.

Термінальним тоном прийнято вважати мелодійні зміни, що реалізуються на останньому наголошеному складі та наступних ненаголошених складах [1]. В ході аудиторського аналізу за характером зміни мелодики наголошених складів у термінальній частині просодичного контуру були виділені: рівень початку тону (реєстр): 1) високий; 2) середній; 3) низький; конфігурація термінального тону: 1) простий (спадний, висхідний, рівний); 2) складний (нисхідний - висхідний, висхідний спадний); 3) складовий (спадний + висхідний, висхідний + спадний).

\section{3. Термінальні тони}

Першим етапом аудиторського аналізу став опис частотності, регістра та конфігурацій термінальних тонів. Результати даного етапу 
дослідження мають першорядне значення для складання мовного просодичного портрета особистості американців різного віку, тому, на думку автора, доцільно почати опис експериментальної частини цього дослідження саме з результатів аналізу термінальних тонів. Опис експериментальних даних з їх подальшою інтерпретацією проводилося в два ступені: характеристики термінальних тонів, типових для американського непідготовленого монологічного мовлення в цілому незалежно від віку мовця, потім опис термінальних тонів по частотності їх вживання в кожній віковій групі та деякі специфічні особливості їх використання мовцями. Отже, згідно з результатами аудиторського аналізу, мелодика термінальної частини синтагми без урахування та 3 урахуванням вікових особливостей мовців має такі відмінні риси (див. таблицю 1).

Спадні термінальні тони. Загальне: спадні тони складають найбільшу частину термінальних тонів в промові представників усіх вікових груп, що пояснюється монологічним характером досліджуваного тексту, а також відсутністю яскраво вираженого емоційно-експресивного забарвлення мови інформантів (частотність вживання низхідних тонів в порівнянні зіншими термінальними тонами дорівнює $43 \%$ без урахування вікових особливостей). У всіх вікових групах, крім юної, відсоток їх використання максимально високий. Відзначимо, що загальна кількість низхідних тонів в мові збільшується пропорційно віку мовця та підвищення його соціального статусу: $33 \%$ - в юної групі, 46\% - у молоді, 51\% - у людей зрілого віку та $45 \%$ - у літніх американців.

Характерною особливістю промови представників всіх вікових груп $\epsilon$ і те, що більше половини від загального числа низхідних тонів складають високі спадні термінальні тони (всього 23\% без урахування віку): 17\% - у мові представників юної групи, 24\% - в мови молоді, $28 \%$ - у інформантів зрілого віку та $24 \%$ - у літніх американців.

Дане спостереження може бути зв'язано з тим, що високий спадний тон найкращим чином відображає доброзичливе ставлення до співрозмовника, жвавість бесіди та залученість в неї мовця. Найбільш нейтральний середній спадний тон ( $12 \%$ без урахування віку) та низький спадний тон ( $8 \%$ без урахування віку), в цілому не дуже характерний для розмовної мови, мають набагато меншу частотність вживання в не- 


\section{Chapter «Philological sciences»}

\begin{tabular}{|c|c|c|c|c|c|c|c|c|c|c|c|c|c|c|c|c|c|c|c|c|c|c|c|c|}
\hline & 웅 & 눗 & $\approx n$ & 10 & $\infty$ & 于 & & & 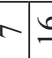 & 0 & in & & -0 & 017 & $r \geqslant$ & $\Xi$ & $a$ & 1 & a & & 14 & $n$ & $n$ & \\
\hline & కై & $\Sigma \infty$ & 1 & $a r$ & - & $\ddot{\sim}$ & 剿 & 1 & $\stackrel{\circ}{\circ}$ & N & $n$ & 케 & $\nu \propto$ & $\infty$ & $1 \cong$ & 가 & 에 $N$ & 1 & $N$ & al & $\because c$ & $\sim$ & 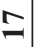 & 의 \\
\hline & E. & $\Sigma 6$ & $m$ & $m$ & ' & 이 & & 1 & 1 & 1 & ' & & $1=$ & $=$ & $1=$ & $=$ & $n$ & 1 & 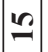 & & $\nabla$ & $\nabla$ & $\infty$ & \\
\hline & & in & ナ & 69 & 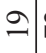 & $N$ & & I & 1 & I & I & & $m 0$ & 96 & 0 & $\underset{\sim}{\infty}$ & ' & 1 & I & & ' & 1 & ' & \\
\hline & a & $\sum$ in & กี & $\infty$ & 0 & i. & & $1-$ & $+c$ & v $v$ & 0 & & N & ปै & ' & \pm & t & 1 & $\nabla$ & & $\stackrel{0}{ }$ & ' & 으 & \\
\hline & 告 & $\sum \%$ & $\because$ & 1 & ㅇ. & 8 & 에 & ' & 1 is & $n$ & $n$ & 예 & 1 ' & $m$ is & $n$ & 8 & cin $n$ & in & 응 & (n) & ' & ' & 1 & mा \\
\hline & 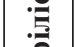 & 我 & 아 1 & -1 & - & in & & I & . & ' & I & & $m \mid \stackrel{c}{c}$ & 이의 & 0.9 & $\stackrel{F}{\forall}$ & ' & $m$ & $m$ & & ' & ' & 1 & \\
\hline & & $\Sigma$ ma & $\infty$ & $\infty \Im$ & 이 & 니 & & I & י & $m$ & $\hat{3}$ & & $\nabla \sigma$ & $6: 5$ & 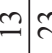 & 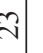 & 으 & 1 & 으 & & 1 & $\nabla$ & $\nabla$ & \\
\hline & m & 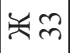 & $\infty$ & Nor & - & $\widehat{\sim}$ & & ' & $1 \nexists$ & $\pm=$ & \pm & & $v \cong$ & $6=$ & $\because$ & $\dot{m}$ & $\infty$ & 4 & $\infty$ & & 10 & $r$ & $r$ & \\
\hline & $\stackrel{1}{d}$ & $\breve{c m}$ & ปิ & $\stackrel{0}{-}$ & $m:$ & $\ni$ & & $m$ & $a / r$ & $m:$ & $n$ & & $m=$ & 6 & 10 & 2 & 0 & 21 & $\underline{-1}$ & & $a$ & I & $a$ & \\
\hline 2 & $\hat{\varepsilon}$ & $\Sigma \bar{m}$ & $\sim ?$ & $\infty$ & v & $\curvearrowright$ & 위 & & $N r$ & $\lambda$ & 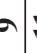 & $=1$ & $1 \subsetneq$ & 잉 & $\mathrm{N}$ & $\mathcal{F}$ & $\stackrel{\mathbb{N}}{\sim}$ & 1 & $\stackrel{\sim}{\Delta}$ & $\cong$ & $N$ & ' & $N$ & $|n|$ \\
\hline$\Xi$ & క్ & 굿요 & $\vec{m}$ & $\vec{m} 0$ & $\infty$ & 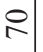 & & & $=1$ & 1 & $n$ & & $\infty$ & ' & $1 \propto$ & $\infty$ & ' & 1 & I & & $\nabla$ & $\nabla$ & $\infty$ & \\
\hline .5 & $\Sigma$ & $\Sigma$ ㄱ. & 守 & 2 & 6 & $N$ & & $1 \mathrm{c}$ & $m 1$ & . & $m$ & & $m \cong$ & $m \curvearrowright$ & $m 0$ & 2 & 6 & 1 & 6 & & 1 & ' & 1 & \\
\hline 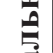 & & $\Sigma n$ & $m$ & 6 & $a$ & $\stackrel{\infty}{+}$ & & $1 \mathrm{c}$ & $m .1$ & . & $m$ & & $m \mid \stackrel{\circ}{\circ}$ & ले & 0 & $\underset{+}{+}$ & ' & 1 & I & & ' & I & I & \\
\hline. & & ำ & $=$ & ' & $1:$ & 二 & & ' & 1 & ' & I & & $m \mid \varnothing$ & $\infty$ & $1 \mid \tilde{\alpha}$ & $\infty$ & ' & ' & ' & & I & ' & ' & \\
\hline 훙 & iิ & 금 & 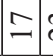 & $\approx=$ & $\because:$ & $i$ & & 1 & $\simeq \nabla$ & + & $\stackrel{2}{\approx}$ & & $\nabla \nabla$ & $\nabla$ & $1 \propto$ & $\infty$ & $N$ & 10 & $\simeq$ & & $\nabla$ & 6 & 으 & \\
\hline & A & $\Sigma I$ & 응 & $\mathrm{N}$ & 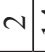 & \pm & ला & 1 & 10 & E & E & (9) & $N G$ & 8.7 & $-i$ & 6 & ' & . & I & $\nabla$ & ' & I & 1 & $\sim$ \\
\hline &. $\bar{e}$ & $\Sigma=$ & 으 & 69 & $\approx$ & ภे & & $1 \mathrm{c}$ & $v \stackrel{r}{c}$ & $n$ & $n$ & & $1 \subseteq$ & 이뇨 & $\because 2$ & $\sqrt{2}$ & 6 & 1 & 0 & & $\sim$ & I & $N$ & \\
\hline & & & 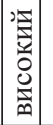 & : & 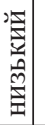 & & & 梽 & 잉 & 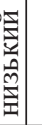 & & & 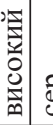 & 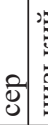 & 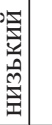 & & & & & & & & & \\
\hline & $\frac{1}{0}$ & & $\mid$ & & & 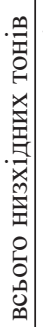 & 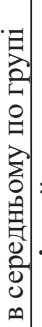 & 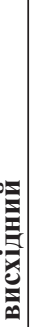 & & & 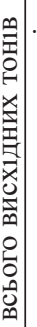 & 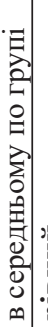 & 产 & & & 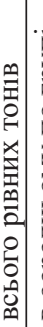 & 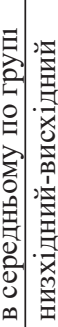 & 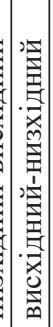 & 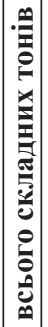 & 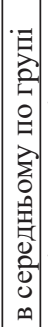 & 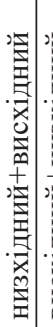 & 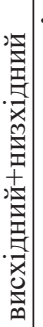 & 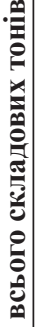 & 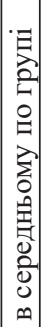 \\
\hline
\end{tabular}


підготовленому монологічному мовленні. Тут були отримані наступні результати: 7\% та 8\% для середнього та низького низхідних тонів - в юної групі, 17\% та 5\% відповідно - в групі молоді, $8 \%$ та $14 \%$ - в мові представників зрілого віку, 16\% та 5\% - у літніх людей. Дані про переважання низхідних термінальних тонів, у синтагмі повністю відповідають висновкам, зробленим в ході попередніх досліджень просодії американської мови. Більшість фонетистів, які вивчають американську просодію, вказують на превалювання низхідного тону в термінальній частині висловлювання в спонтанному монологічному мовленні $[2 ; 4 ; 8 ; 9 ; 11 ; 14]$. Так, Н.Г. Углова, яка вивчає особливості мелодики та темпу дикторської мови, відзначає, що специфіка даного стилю полягає в тому, що переваги рівних тонів не виявлено. Домінуюче становище займають спадні тони різного діапазону (65,6\%), які «виконують роль контрасту по відношенню до переважаючої рівної шкали, тим самим виділяючи на іiі тлі істотну фактичну інформацію» [11, с. 126].

Специфічне: Лідерство за кількістю низхідних тонів в мові займає група американців зрілого віку (51\%), що цілком зрозуміло впливом високого соціального статусу, придбаного до 50 років, на чітко вироблений стиль мовної поведінки, а також на більш впевнену та авторитетну манеру вести бесіду. Найменша кількість низхідних тонів відзначено в групі юних інформантів (33\%), де лідируючим є рівний тон.

Висхідні термінальні тони. Загальне: частотність вживання висхідних тонів в кінці синтагми значно нижче в порівнянні з кількістю низхідних тонів в тому ж положенні (частотність їх вживання в порівнянні з іншими термінальними тонами дорівнює 14\% без урахування віку). В аналізованих монологічних уривках висхідний термінальний тон, безумовно, носить апелятивний характер, використовується для підтримки розмови при зверненні до співрозмовника, тим самим реалізуючи комунікативну функцію, оскільки досліджуваний звуковий матеріал являє собою уривок з інтерв'ю. Так, юні американці використовують висхідний тон як термінальний в 15\% випадків, молодь - у 11\%, американці зрілого та похилого віку завершують їм фразу в $10 \%$ та 20\% випадків відповідно. Порівняно невелика кількість висхідних тонів, зафіксованих у мові інформантів, свідчить про монологічний характер досліджуваного тексту, завершеності більшості синтагм i, отже, про бесіду, тематика якої не представляла осо- 
бливої складності для сприйняття та породження мовного висловлювання мовцями.

Згідно з результатами, отриманими в ході проведення даного дослідження вживання високого висхідного тону було зафіксовано лише в одиничному випадку (у мові одного з представників молодіжної групи), тому складно робити, будь-які висновки про частотність вживання високого висхідного термінального тону в спонтанному монологічному мовленні американців різних вікових груп. Отже, в ході нашого експерименту не підтвердилося існування описуваної в зарубіжній літературі тенденції до використання високого висхідного тону в стверджувальних висловлюваннях, в тому числі і молодими американцями. Середній та низький висхідний термінальні тони (всього 5\% та 8\% без урахування віку) американці різного віку використовують в наступному співвідношенні: $3 \%$ та $11 \%$ - показники частотності вживання середнього та низького висхідного тону в мові представників юної групи, майже рівне співвідношення 6\% і 5\% відповідно - в групі молоді, $1 \%$ та $9 \%$ - у інформантів зрілого віку, $12 \%$ та $8 \%$ - у літніх людей. Специфічне: найбільша кількість висхідних термінальних тонів відзначена в промові юних (15\%) та літніх американців (20\%). Можливим поясненням цього явища може служити невпевненість в собі, а також невміння авторитетно і категорично висловлюватися, що в цілому характерно для юнацького віку. У літньому віці невпевненість, виражена висхідним термінальним тоном, пов'язана 3 виходом на пенсію i, як наслідок, з кардинальними змінами способу життя, із зниженням соціального статусу та суспільної значимості людини, а також з втратою багатьох можливостей самореалізації.

Рівні термінальні тони. Загальне: як відомо, американська мова характеризується використанням великої кількості рівних тонів $[3 ; 6 ; 8]$, що знайшло підтвердження і в проведеному нами дослідженні (частотність вживання рівних тонів в порівнянні з іншими термінальними тонами дорівнює 30\% без урахування віку). Так, юні американці використовують рівний термінальний тон в 47\% випадків, молодь - у $24 \%$, люди зрілого віку - в 32\%, а літні жителі США - в 16\% випадків.

Ще однією особливістю мелодики термінальної частини синтагми, зазначеної в промові представників усіх вікових груп, є те, що для більшої частини рівних тонів характерний середній рівень початку 
(24\% з 30\% без урахування віку: 39\%, 17\%, 22\% та 13\% випадків в кожній групі відповідно). Низьким рівним тоном (5\% без урахування віку) закінчують синтагму юні інформантів в 6\% випадків, в 4\% - молодь, в 7\% - представники зрілого віку та всього в 2\% - літні американці. Вживання високого рівного термінального тону було зафіксовано лише в окремих випадках ( $2 \%$ без урахування віку), що, на нашу думку, пов'язано, перш за все, з його високим ступенем емоційності. Тут було виявлено наступне процентне співвідношення віку та частотності вживання: $2 \%$ у представників юної групи та зрілого віку, трохи більший показник у молоді - 3\%, літні люди дуже рідко використовують високий рівний термінальний тон, всього в 1\% випадків. Специфічне: лідерство за кількістю рівних термінальних тонів, безумовно, займає юна група інформантів (47\%), що пояснюється невпевненістю в собі та невмінням чітко і однозначно формулювати думку навіть в межах побутової тематики. Даний висновок повністю підтверджується результатами експериментального дослідження В.В. Яскевича $[14$, c. 9]. Найменшу кількість рівних тонів було відзначено в групі літніх жителів США (16\%). Певні висновки можна зробити і щодо вживання мовцями складних та складових термінальних тонів.

Складні та складені термінальні тони. Загальне: згідно $з$ даними попередніх експериментальних досліджень американської просодії, складні тони, а саме складний низхідний-висхідний тон, мають високу частотність вживання в американській мови [3; 12], що не підтвердилося під час нашого експерименту. Як показали результати проведеного нами аудиторського аналізу, в непідготовленому монолозі американці набагато рідше вживають складні та складені термінальні тони в порівнянні з простими тонами, що природним чином випливає з спонтанного характеру досліджуваного звукового матеріалу.

Так, складні термінальні тони (всього 8\% без урахування віку) були відзначені в промові представників різних вікових груп в такій кількості: складним низхідним-висхідним тоном (7\% без урахування віку) завершують синтагму юні американці в 2\% випадків, молодь - у $13 \%$, люди зрілого віку - у 4\%, та літні жителі США - 9\% випадків. На частку складного висхідного-спадного тону доводиться тільки 1\% використання без урахування вікових особливостей. Його вживання в термінальної частини синтагми було зафіксовано в кількості $2 \%$ лише в мові юної та 
зрілої вікових груп, тому не представляється можливим робити будьякі висновки щодо частотності його появи в мові в залежності від віку мовця. Кількість складових термінальних тонів, зазначених у промові інформантів різних вікових груп, не перевищує 5\% без урахування віку, що становить мінімальну частину від загальної кількості термінальних тонів в уже згадуваному звуковому матеріалі. Таким чином, складовий спадний + висхідний термінальний тон (3\% без урахування віку) був зафіксований у представників різних вікових груп в наступному процентному вираженні: 1\% - у мові юних інформантів, 3\% - у молоді, $2 \%$ у американців зрілого віку та 6\% - у мові літніх людей. Частотність вживання складеного висхідного + спадного термінального тону $(2 \%$ без урахування віку) має схоже процентне співвідношення: 1\% виявлено в промові юних інформантів та представників зрілої вікової групи, 2\% у молоді та 4\% - у літніх американців.

Специфічне: як показали результати аудиторського аналізу, більшу кількість складних та складових термінальних тонів присутні у мові молоді (12\% складних та 5\% складових термінальних тонів) і частково зберігається у представників літнього віку (9\% та 10\% відповідно). Наявність даної тенденції, на нашу думку, пов'язано з умінням представників старшого покоління доцільно використовувати весь репертуар просодичних моделей для вираження думок.

За результатами аудиторського аналізу частотності, регістра та конфігурацій термінальних тонів, американське монологічне мовлення непідготовленого характеру в цілому, а також вікові особливості його просодичного оформлення можна охарактеризувати наступним чином: 1) в американському монологічному мовленні непідготовленого характеру переважають низхідні термінальні тони (43\%), більше половини 3 яких складають високі спадні тони (23\%). Як і слід було очікувати, рівні тони, характерні для американської мови в цілому, були виявлені в мовленні інформантів в значній кількості (30\%), велика частина 3 них має середній рівень початку (24\%). Низька частотність висхідних конфігурацій, а також складних та складових термінальних тонів дозволяє зробити висновок про те, що тони даного типу не $є$ характерними для спонтанного монологу в американському варіанті англійської мови; 2) юнацька група інформантів лідирує за кількістю рівних термінальних тонів, які використовуються в монолозі і додають мови відтінок 
невпевненості та незавершеності (47\%). Незважаючи на низьку частотність висхідних тонів в цілому, юні американці використовують їх в досить великій кількості в порівнянні з представниками інших вікових груп (15\%). Результатом невпевненості в собі та невміння чітко формулювати думку стало також найменшу кількість тих, які сходять тонів, зафіксованих у мові юних інформантів (33\%); 3) молодіжна група помітно відрізняється від юнацької по деяких особливостей мелодійного оформлення висловлювання. Молоді американці набагато ширше використовують спадні конфігурації (46\%), що говорить про наявність у них певною мірою впевненості в собі і в своїх словах, а також про придбання ними навичок володіння власним голосом. Молоді інформантів розширюють свій репертуар мелодійних конфігурацій використанням складних та складових термінальних тонів (12\% та 5\% відповідно), що, безумовно, робить їх мову багатше і різноманітніше в музичному плані; 4) мова американців зрілого віку характеризується найбільшим набором просодичних моделей i, отже, найбільш багатим мелодійним малюнком. Інформанти зрілого віку вживають найбільше низхідні термінальні тони (51\%) та найменше висхідних (10\%), що пов'язано з придбанням-високого соціального статусу, престижною та високооплачуваною роботою, повагою колег та, як наслідок, впевненою та авторитетної манерою ведення бесіди. Різноманітність мелодійного малюнка проявляється у використанні складних та складених конфігурацій, які характерні для мови представників старших вікових груп; 5) літні американці частково зберігають різноманітність мелодійного малюнка, в їхній мові присутні основні просодичні конструкції, включаючи складні та складені термінальні тони (9\% та 10\% відповідно). Мова літніх інформантів характеризується використанням найбільшої кількості висхідних тонів (20\%) і найменшою кількістю рівних тонів (16\%) у порівнянні з промовою представників інших вікових груп, що, швидше за все, пов'язано зі зниженням активності та 3 втратою впевненості в собі.

\section{4. Предтермінальна частина}

Однонаголошена шкала. Наступним етапом аудиторського аналізу став опис частотності та рівня початку (регістра) однонаголошеної шкали, тобто шкал, що характеризуються наявністю одного ударного 
складу. В ході експерименту з'ясувалося, що подібного роду шкали складають приблизно одну третину від загальної кількості всіх використовуваних шкал (32\% без урахування віку). Дане спостереження цілком логічно, так як аналізований звучить матеріал являє собою непідготовлену розмовну мову, для якої типовим $є$ наявність коротких незакінчених синтагм, а також еліптичних та хезітаційних конструкцій.

Видається неможливим виявити вікову специфіку використання однонаголошених шкал, оскільки в ході аудиторського аналізу було відзначено майже дорівнює їх співвідношення в мові представників усіх вікових груп (див. таблицю 2). Так, юні, молоді та американці зрілого віку вживають однонаголошені шкали в $34-35 \%$ випадків, трохи менше їх зафіксовано в мові літніх людей - $26 \%$ від загальної кількості всіх використовуваних шкал.

Важливим, на наш погляд, $є$ той факт, що більша частина однонаголошених шкал розташована в межах високого та середнього регістрів (50\% - в високому регістрі, $33 \%$ - в середньому та $17 \%$ - в низькому регістрі без урахування вікових особливостей). Оскільки даний звуковий матеріал являє собою уривки з відповідей на запитання під час інтерв'ю, в ході якого інформанти вели вільну бесіду на побутову тематику, що не представляє для них особливої складності, використання високого та середнього регістрів відображає позитивний настрій учасників експерименту. Високий початок також має на увазі ввічливе та доброзичливе ставлення до співрозмовника, відкритість, захопленість бесідою та інтерес з боку мовця.

Отже, максимальна кількість однонаголошених шкал, що мають високий рівень початку, було відзначено в промові юних американців (67\%), трохи нижче даний показник у молоді (37\%), інформанти зрілого та похилого віку починають однонаголошену шкалу з високого рівня в майже рівному співвідношенні 48\% та 50\% відповідно. Найбільша кількість однонаголошених шкал, що мають середній рівень початку, було відзначено в мовленні молоді (51\%), представники інших вікових груп мають значно нижчі показники: 20\% - у юних інформантів, $31 \%$ - у людей зрілого віку та 28\% - у мові літніх американців. Частотність використання низького рівня початку як більш стриманого, офіційного, а іноді і негативно забарвленого не перевищує $20 \%$ в жодній віковій групі: 13\% та 12\% використання зазначено в промові 


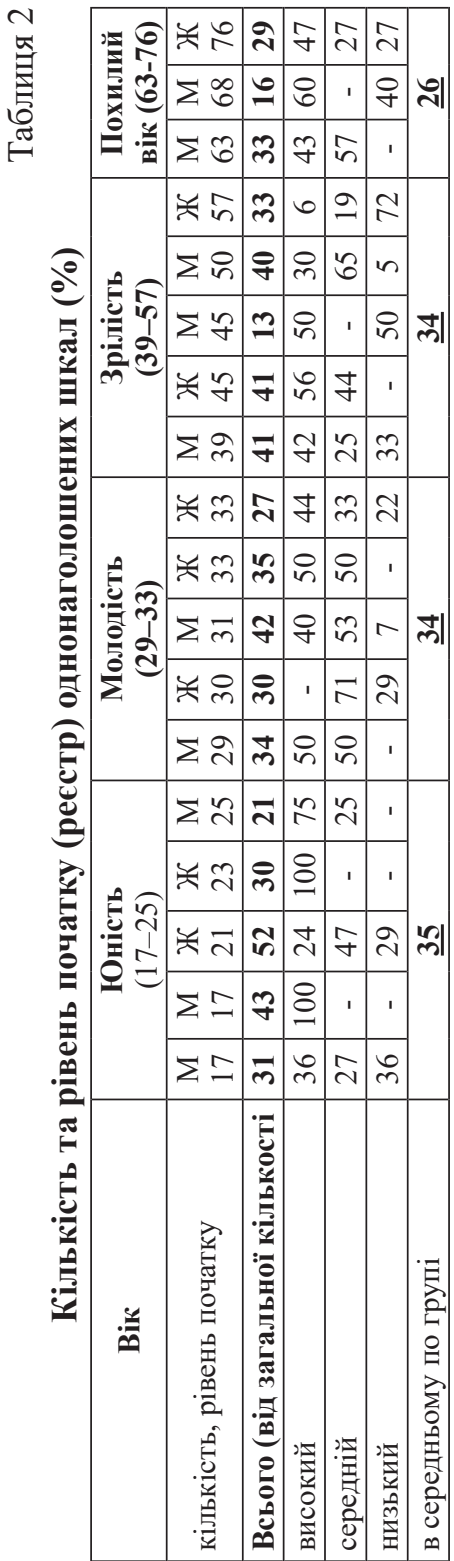

юних молодих американців, 22\% у представників зрілої та літньої груп.

Таким чином, описуючи результати, отримані в ході аналізу частотності та рівня початку (регістра) однонаголошених шкал, необхідно сказати наступне:

1) частотність вживання однонаголошених шкал у непідготовленій мови монологічного характеру досить істотна та дорівнює однієї третини від загальної кількості всіх використовуваних шкал $(32 \%) ; 2)$ кількість уживаних однонаголошених шкал в мові не залежить від віку мовця, раніше зазначену кількість було виявлено в промові представників усіх вікових груп; 3) більшість однонаголошених шкал знаходиться в межах високого регістру, що пояснюється характерними для високого початку ознаками, такими як позитивна забарвленість, вираз відкритості та зацікавленості мовця, а також прояв уваги до співрозмовника з боку мовця.

\section{5. Більш складні конфігурації}

На завершальному етапі аудиторського аналізу були розглянуті наступні параметри предтермінальної частини синтагми: рівень початку (реєстр) та тип шкали за характером зміни мелодики, характерні для американців різних вікових груп і зафіксовані в ході аналізу непідготовленої монологічної розповіді. На даному 
етапі експерименту було виявлено, що жодна вікова група не володіє яскраво вираженою специфікою вибору рівня початку шкали та її типу, отримані дані відносно однорідні, не були виявлені різкі між групові відмінності. Так як коливання процентного співвідношення частотності вживання тієї чи іншої шкали між групами виявилися невеликі, представляється можливим лише узагальнити отримані результати і описати найбільш істотні тенденції в просодичному оформленні предтермінальної частини синтагми, характерні для непідготовленої монологічного мовлення американців (див. таблиці $3,4,5$ ).

Згідно 3 результатами аудиторського аналізу предтермінальної частини синтагми з'ясувалося, що половина всіх досліджуваних синтагм починається на високому рівні (50\% без урахування вікових особливостей), відсоток використання середнього регістра також досить високий ( $38 \%$ без урахування віку) (див. Таблицю 6). Цей факт пояснюється тим, що високий початок забезпечує швидке встановлення контакту мовця i слухача, допомагає справити приємне враження, а також висловити тепле та дружнє ставлення до співрозмовника. Дане пояснення $є$ актуальним і в рамках цього дослідження. Незважаючи на те, що аналізований звуковий матеріал являє собою монологічну розповідь, важливо, що він $є$ уривком з бесіди під час інтерв'ю, де необхідно дотримання етикету та прояв ввічливості з боку оповідача. Таким чином, вживання низького початку як більш стриманого та холодного було відзначено лише в невеликій кількості випадків (12\% без урахування віку).

Аналізуючи вікові особливості використання регістрів в предтермінальній частині висловлювання, необхідно ще раз відзначити відносну однорідність вибору рівня початку синтагми. Так, юні інформантів та американці зрілого віку в більшій мірі використовують високий рівень початку (60\% та 53\% відповідно), на частку середнього регістра в цих вікових групах припадає $27 \%$ та $34 \%$ відповідно. У промові молоді зафіксовано приблизно рівне співвідношення використання високого (43\%) та середнього (46\%) регістрів. У представників літньої вікової групи відзначено лише $38 \%$ високого початку та 50\% середнього, що може бути пов' язано із загальним віковим звуженням діапазону голосу. Кількість низького початку синтагми не перевищує $11-13 \%$ у всіх вікових групах: 13\% - у мові юних та літніх людей, 11\% - у молоді та $12 \%$ - у американців зрілого віку. 


\section{Nataliia Koval}

瓷

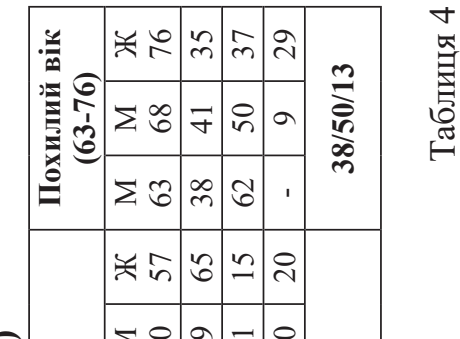

预

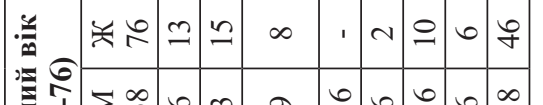

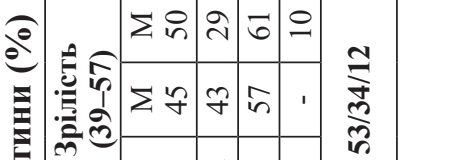



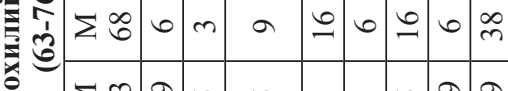

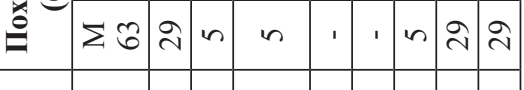



终

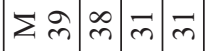

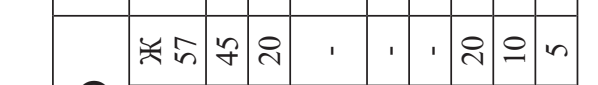

¿̂̃

in $\sum \circ \pi$ ก

ले

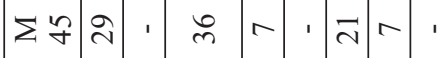

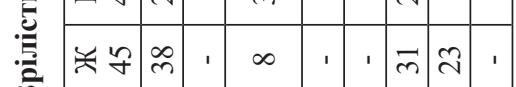

导

늣 요 은

ले

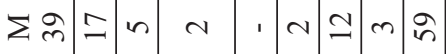

ฮิ

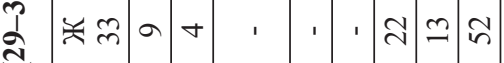

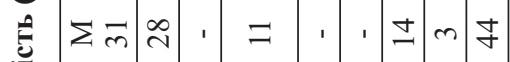

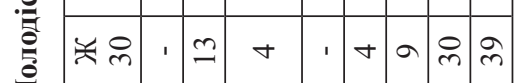

$\Sigma$ ปे $\stackrel{\infty}{+}$ in .

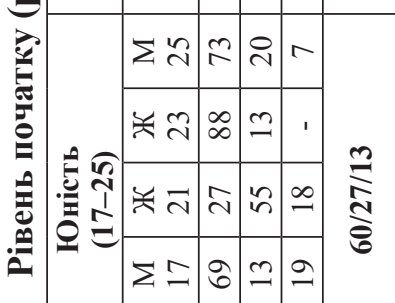

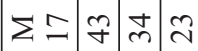

$\stackrel{0}{2}$

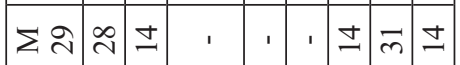

|

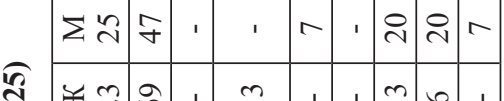

Tิ

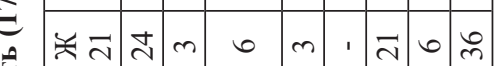

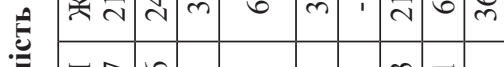

อิ

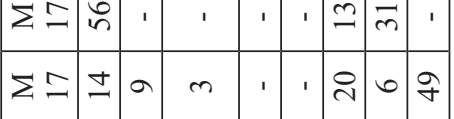

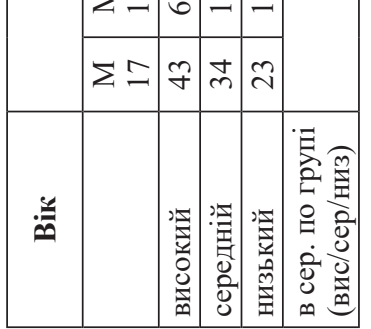

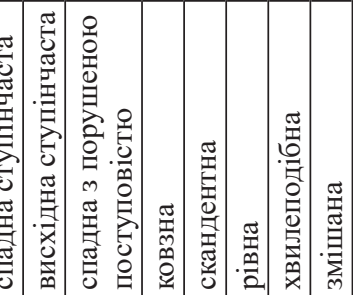




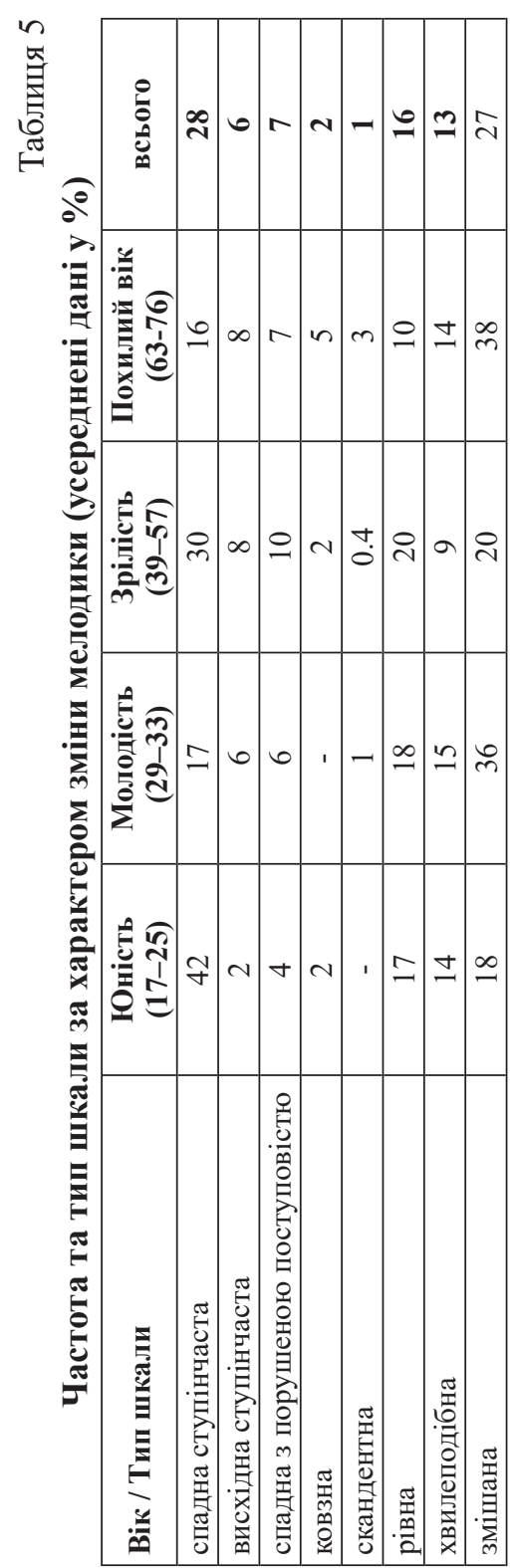

В ході дослідження типу шкали за характером зміни мелодики було виявлено, що найбільш часто використовуваними шкалами є спадна ступінчаста $(28 \%$ від загальної кількості шкал без обліку вікових особливостей $)$, змішана $(27 \%$ без урахування віку) та рівна (16\% без, обліку віку) (див. таблиці 7,8$)$. Дані нашого експерименту частково підтверджуються результатами попередніх досліджень, згідно з якими найбільш високим коефіцієнтом частотності в американській мови 3 низьким або середнім ступенем емоційності $є$ спадна хвилеподібна, рівна та рівна хвилеподібна шкали [12]. Вживання, шкал даного типу в аналізованій ситуації спілкування цілком обгрунтовано, тому що всі вони є стилістично нейтральними та не володіють яскраво вираженою емоційною забарвленістю. Так, найбільший відсоток використання низхідної ступінчастої шкали пояснюється монологічним характером досліджуваного тексту, де переважають позитивні висловлювання розповідного типу. Наявність змішаної шкали $є$ типовою ознакою непідготовленої мови, а використання великої кількості рівних шкал характерно для американської мови в цілому, особливо в ході розмови на побутові теми, де переважає розмовний стиль 
ведення бесіди. Необхідно відзначити значний відсоток використання хвилеподібних шкал (13\% без урахування віку) також характерних для американської мови.

Відповідно, кількість емоційна забарвлених шкал, зафіксованих у мові учасників експерименту, набагато менше (не більше 7\%), і воно являє собою наступне процентне співвідношення (без урахування вікових особливостей): висхідна ступінчаста - $6 \%$, спадна ступінчаста 3 порушеною поступовістю - 7\%, змінна - 2\% та скандентна $-1 \%$. Слід зауважити, що спадна ступінчаста шкала з порушеною поступовістю була нами віднесена в цю групу виключно через досить низьку частотність іï вживання в мові, що, безумовно, наділяє дану шкалу додатковим експресивним забарвленням.

Говорячи про вікові особливості використання різних типів шкал, необхідно ще раз вказати на значний ступінь однорідності у виборі конфігурації шкали серед представників різних вікових груп. Так, юні інформанти лідирують за кількістю використання низхідної ступінчастої шкали (42\%), досить високий відсоток вживання даної шкали зафіксований в мові американців зрілого віку (30\%), в групі молоді та людей похилого віку показники дещо нижчі: 17\% та 16\% в кожній групі відповідно. Однак саме в цих вікових групах широко використовується змішаний тип шкали: $36 \%$ - у мові молоді та $38 \%$ - у літніх людей, в той час як для мови юних та зрілих американців були виведені показники $18 \%$ та 20\% відповідно. Наступний тип шкали, найбільш характерний для непідготовленого монологу жителів США, представлений рівною шкалою. Тут не було відзначено значних коливань в залежності від віку мовця, показники схожі в перших трьох вікових групах (17\% - у юних інформантів, $18 \%$ - у молоді, $20 \%$ - у зрілих американців), представники старшої групи вживають рівну шкалу в меншій кількості випадків (10\%). Відсоток використання хвилеподібної шкали досить високий, проте не перевищує $15 \%$ в жодній віковій групі. Найменше хвилеподібних шкал було зафіксовано в мові представників зрілого віку (9\%), у юних та літніх людей відсоток використання трохи вище (14\%), а в мовленні молоді кількість досягає $15 \%$.

Певні висновки можна зробити і щодо вживання емоційно забарвлених шкал американцями різного віку. В цій групі шкал, безумовно, лідирують спадна ступінчаста шкала з порушеною поступовістю та висхід- 
на-ступінчаста шкала. Майже у всіх вікових групах показники трохи вище для низхідної ступінчастої шкали з порушеною поступовістю: $4 \%$ - у юних інформантів, $6 \%$ - у молоді, $10 \%$ - у мові представників зрілого віку та 7\% - в групі літніх людей. Висхідна ступінчаста шкала вживається у $8 \%$ випадків у мові зрілих та літніх американців, трохи нижче показники для молоді (6\%) - і лише 2\% використання зазначено у мові юних інформантів. Наявність ковзної та скандентної шкал в мові характерно, в основному, для представників старшого покоління: 5\% для ковзної та 3\% для скандентної шкал. В інших вікових групах показники не перевищують 1-2\%, тому важко робити якісь висновки відносно специфіки їх використання в мові в залежності від віку мовця.

Підводячи підсумки аналізу предтермінальної частини синтагми в рамках непідготовленого монологічного розповіді, необхідно сказати, що 1) для мови інформантів всіх вікових груп характерний високий початок синтагми як більш відкритий, привітний та доброзичливий, який допомагає встановити особистий контакт зі співрозмовником та справити на нього приємне враження; 2) представники старшої вікової групи в більшості випадків починають синтагму з середнього регістра голосового діапазону, що може бути пов'язано із загальною тенденцією до вікового звуження діапазону голосу літніх людей; 3) аналіз змін предтермінальної частини синтагми виявив переважання низхідної ступінчастої, змішаної, рівної та хвилеподібної типів шкал як найбільш нейтральних в стилістичному плані та тих, які не володіють яскраво вираженим емоційним забарвленням; 4) відсоток використання емоційно-експресивних типів шкал в аналізованої ситуації спілкування невисокий, що пов'язано з монологічним характером досліджуваного тексту, а також з його стилістичною однорідністю.

\section{6. Висновки}

Просодична характеристика американського непідготовленого монологічного мовлення. Згідно з результатами, отриманими в ході проведеного нами аудиторського аналізу мелодійних особливостей, американське непідготовлене монологічне мовлення в цілому можна охарактеризувати наступним чином:

1. Термінальні тони: спадні тони складають найбільшу частину термінальних тонів в промові представників усіх вікових груп (43\%), 
крім юної. Необхідно відзначити, що загальна кількість низхідних тонів в мові збільшується пропорційно віку мовця та підвищенню його соціального статусу: $33 \%$ - у юних інформантів, $46 \%$ - у молоді, $51 \%$ - у людей зрілого віку і $45 \%$ - у літніх американців. Характерною особливістю мови представників усіх вікових груп $\epsilon$ і те, що більше половини від загального числа низхідних тонів складають високі спадні термінальні тони (23\% без урахування віку).

Частотність вживання висхідних тонів в кінці синтагми значно нижче в порівнянні з кількістю низхідних тонів в тому ж положенні (14\%). Наявність високого висхідного тону було виявлено лише в одиничному випадку, отже, дане дослідження не підтвердило існування описуваної в зарубіжній літературі тенденції до використання високого висхідного тону в стверджувальних висловлюваннях, в тому числі і молодими американцями.

Американське монологічне мовлення в цілому характеризується використанням великої кількості рівних тонів, що знайшло підтвердження і в ході цього дослідження. За результатами нашого експерименту, рівні тони складають $30 \%$ від загальної кількості всіх використовуваних тонів, велика частина з яких починається на середньому рівні голосового діапазону (24\%).

У непідготовленому монолозі американці набагато рідше вживають складні та складені термінальні тони в порівнянні з простими тонами, проте відсоток використання складних термінальних тонів, трохи вище, ніж складових (8\% проти 5\% відповідно). Найбільшою частотністю вживання в порівнянні з іншими складними тонами володіє складний низхідний висхідний тон (7\%).

2. Предтермінальна частина (шкала): однонаголошені шкали складають приблизно одну третину від загальної кількості всіх використовуваних шкал (32\%), вказана кількість не залежить від віку мовця, так як вона була виявлена в промові представників всіх вікових груп. Більшість однонаголошених шкал знаходиться в межах високого регістру. На нашу думку, наявність однонаголошених шкал в мові цілком обгрунтовано, тому що аналізований звуковий матеріал являє собою непідготовлену розмовну мову, для якої типовою є наявність коротких незакінчених синтагм, а також еліптичних та хезітаційних конструкцій. В цілому необхідно підкреслити, що високий рівень по- 
чатку характерний для половини всіх досліджуваних синтагм (50\%), відсоток використання середнього регістра також досить високий (38\%). Цей факт пояснюється тим, що високий початок фрази забезпечує швидке встановлення контакту мовця і слухача, допомагає справити приємне враження, а також висловити тепле та дружне ставлення до співрозмовника.

В ході дослідження типу шкали за характером зміни мелодики було виявлено, що найбільш часто використовуваними шкалами $є$ спадна ступінчаста (28\%), змішана (27\%) та рівна (16\%). Вживання шкал даного типу, в аналізованої ситуації спілкування цілком обгрунтовано, тому що всі вони є стилістично нейтральними та не володіють яскраво вираженою емоційною забарвленістю. Необхідно відзначити значний відсоток використання хвилеподібних шкал (13\%), також характерних для американської мови. Відсоток використання емоційно-експресивних типів шкал в аналізованої ситуації спілкування невисокий, що пов'язано з монологічним характером досліджуваного тексту, а також 3 його стилістичною однорідністю.

Головним висновком проведеного нами дослідження можна вважати підтвердження того факту, що для кожного віку існує своя специфіка просодичного оформлення висловлювання, яка виражається в певному наборі мелодійних особливостей, типових для мовлення представників тієї чи іншої вікової групи. Коротко виявлену вікову специфіку непідготовленого монологічного мовлення американців можна викласти наступним чином:

1) юнацька група інформантів (17-25 років) лідирує за кількістю рівних термінальних тонів, які використовуються в монолозі і додають мови відтінок монотонності, а також невпевненості та незавершеності (47\%). Незважаючи на низьку частотність висхідних тонів в цілому, юні американці використовують їх в досить великій кількості в порівнянні з представниками інших вікових груп (15\%). Результатом невпевненості в собі та невміння чітко формулювати думку стало також найменшу кількість низхідних тонів, зафіксованих у мові юних інформантів (33\%); 2) молодіжна група (25-35 років) помітно відрізняється від юнацької по деяким особливостям мелодійного оформлення висловлювання. Молоді люди набагато ширше використовують спадні конфігурації (46\%), що говорить про наявність у них певною мірою 
впевненості в собі і в своїх словах, а також про придбання ними навичок володіння власним голосом. Молоді інформанти розширюють репертуар мелодійних конфігурацій використанням складних та складових термінальних тонів (12\% та 5\% відповідно), що, безумовно, робить їх мову багатше та різноманітніше в музичному плані;

3) мова американців зрілого віку (35-55/60 років) характеризується найбільшим набором просодичних моделей i, отже, найбільш багатим мелодійним малюнком. Інформанти зрілого віку вживають найбільше низхідних термінальних тонів (51\%) і найменше висхідних (10\%), що пов'язано з набуттям високого соціального статусу, престижної високооплачуваної роботи, поваги колег та, як наслідок, впевненої та авторитетної манери ведення бесіди. Різноманітність мелодійного малюнка проявляється у використанні складних та складених конфігурацій, які характерні для мови представників старших вікових груп;

4) літні американці (60-80 років) частково зберігають різноманітність мелодійного малюнка, в їхній мові присутні основні просодичні конструкції, включаючи складні та складені термінальні тони (9\% i 10\% відповідно). Мова літніх інформантів характеризується використанням найбільшої кількості висхідних тонів апелятивного характеру (20\%) та найменшою кількістю рівних тонів (16\%) у порівнянні 3 промовою представників інших вікових груп.

Таким чином, беручи до уваги отримані нами результати, можна зробити висновок, що динаміка просодичних змін до мови людини протягом його життя дійсно має місце, і обумовлена вона біологічними, психологічними та соціальними факторами. Особистість людини являє собою складну єдність вищевказаних складових, які знаходяться в постійній взаємодії та які безпосередньо впливають на мовну поведінку індивіда. Отже, вивчення процесу мовотворення та виявлення його специфіки на певному етапі життя людини можливо тільки при комплексному підході до вивчення особистості, що враховує все різноманіття факторів, які впливають на неї. Все це зумовлює подальші дослідження в цьому напрямку.

\section{Список літератури:}

1. Васильев В.А. Фонетика английского языка: Нормативный курс. Москва : Высшая школа, 1980. 256 с. 
2. Дорохова М.В. Ритмическая организация американской речи : автореф. ... канд. филол. наук. Москва, 1996. 22 с.

3. Жаворонкова И.А. Система терминальных тонов в американском, варианте английского языка (экспериментально-фонетическое исследование) : автореф. ... канд. филол. наук. Москва, 1990. 20 с.

4. Леонтьева Н.А. Роль просодии в организации радиоинтервью (экспериментально-фонетическое исследование на материале американского варианта английского языка) : автореф. ... канд. филол. наук. Москва, 1983. 23 с.

5. Лингвистический энциклопедический словарь / под ред. В.Н. Ярцевой. Москва : «Советская энциклопедия», 1990. С. 401-402.

6. Ощепкова В.В. Язык и культура Великобритании, США, Канады, Австралии, Новой Зеландии. Москва : Изд-во «Глосса-Пресс», 2004. 336 с.

7. Палагина Н.Н. Психология развития и возрастная психология : Учебное пособие для вузов. Москва, 2005. 288 с.

8. Полетаев Д.И. Социальная дифференциация интонации в ограниченном речевом сообществе (экспериментально-фонетическое исследование на материале речи жителей г. Анкориджа, штат Аляска, США) : автореф. ... канд. филол. наук. Москва, 1997. 26 с.

9. Постникова Л.В. Просодия и политический имидж оратора (на материале речей американских президентов) : автореф. ... канд. филол. наук Москва, 2003. 19 с.

10. Потапова Р.К. Речь: коммуникация, информация, кибернетика : Учебное пособие. Москва : Эдиториал УРСС, 2001. 568 с.

11. Углова Н.Г. Специфика мелодики и темпа дикторской речи (экспериментально-фонетическое исследование на материале информационных программ американского телевидения) : автореф. ... канд. филол. наук. Москва, 2006. 24 c.

12. Шахбагова Д.А. Фонетические особенности произносительных вариантов английского языка. Москва : Высшая школа, 1982. 128 с.

13. Якутина М.В. Просодические формы речевого поведения участников судебного процесса (экспериментально-фонетическое исследование на материале аудиозаписей Верховного Суда США) : автореф. ... канд. филол. наук. Москва, 2002. 22 с.

14.Яскевич В.В. Взаимодействие факторов фонетического варьирования (в чтении и спонтанной речи взрослых и подростков в американском варианте английского языка) : автореф. ... канд. филол. наук. Минск : Учреждение «Минский Государственный Лингвистический Университет», 2007. 20 с.

15. Crystal D. A First Dictionary of Linguistics and Phonetics. London : Andre Deutsch, 1980. 390 p.

\section{References:}

1. Vasil'yev V.A. (1980). Fonetika angliyskogo yazyka: Normativnyy kurs [Phonetics of the English Language: A Normative Course]. Moskva: Vysshaya shkola, 256 p. (in Russian) 
2. Dorokhova M.V. (1996). Ritmicheskaya organizatsiya amerikanskoy rechi: avtoref. ... kand. filol. nauk [Rhythmic organization of American speech: abstract ... cand. philol. sciences]. Moskva, 22 p. (in Russian)

3. Zhavoronkova I.A. (1990). Sistema terminal'nykh tonov v amerikanskom, variante angliyskogo yazyka (eksperimental'no-foneticheskoye issledovaniye): avtoref. ... kand. filol. nauk [The system of terminal tones in the American, variant of the English language (experimental-phonetic research): abstract ... cand. philol. sciences]. Moskva, 20 p. (in Russian)

4. Leont'yeva H.A. (1983). Rol' prosodii v organizatsii radiointerv'yu (eksperimental'no-foneticheskoye issledovaniye na materiale amerikanskogo varianta angliyskogo yazyka): avtoref. ... kand. filol. nauk [The role of prosody in organizing radio interviews (an experimental phonetic study based on the American version of the English language): abstract ... cand. philol. sciences]. Moskva, 23 p. (in Russian)

5. Lingvisticheskiy entsiklopedicheskiy slovar' (1990) [Linguistic encyclopedic dictionary] / red. V.N. Yartseva. Moskva: «Sovetskaya entsiklopediya», pp. 401-402. (in Russian)

6. Oshchepkova V.V. (2004). Yazyk i kul'tura Velikobritanii, SSHA, Kanady, Avstralii, Novoy Zelandii [Language and culture of Great Britain, USA, Canada, Australia, New Zealand]. Moskva: Izd-vo «Glossa-Press», 336 p. (in Russian)

7. Palagina N.N. (2005). Psikhologiya razvitiya i vozrastnaya psikhologiya: Uchebnoye posobiye dlya vuzov [Psychology of development and age psychology: Textbook for universities]. Moskva, 288 p. (in Russian)

8. Poletayev D.I. (1997). Sotsial'naya differentsiatsiya intonatsii v ogranichennom rechevom soobshchestve (eksperimental'no-foneticheskoye issledovaniye na materiale rechi zhiteley g. Ankoridzha, shtat Alyaska, SSHA): avtoref. ... kand. filol. nauk [Social differentiation of intonation in a limited speech community (an experimental-phonetic study based on the speech of residents of Anchorage, Alaska, USA): abstract ... cand. philol. sciences]. Moskva, 26 p. (in Russian)

9. Postnikova L.V. (2003). Prosodiya i politicheskiy imidzh oratora (na materiale rechey amerikanskikh prezidentov): avtoref. ... kand. filol. nauk [Prosody and the political image of the orator (based on American presidents' speeches): abstract ... cand. philol. sciences]. Moskva, 19 p. (in Russian)

10. Potapova R.K. (2001). Rech': kommunikatsiya, informatsiya, kibernetika: Uchebnoye posobiye [Speech: communication, information, cybernetics: tutorial]. Moskva: Editorial URSS, 568 p. (in Russian)

11. Uglova N.G. (2006). Spetsifika melodiki i tempa diktorskoy rechi (eksperimental'no-foneticheskoye issledovaniye na materiale informatsionnykh programm amerikanskogo televideniya): avtoref. ... kand. filol. nauk [The specifics of melody and tempo of the speaker's speech (an experimental-phonetic study based on the material of the American television news programs): abstract ... cand. philol. sciences]. Moskva, 24 p. (in Russian)

12. Shakhbagova D.A. (1982). Foneticheskiye osobennosti proiznositel'nykh variantov angliyskogo yazyka [Phonetic features of pronunciation variants of the English language]. Moskva: Vysshaya shkola, 128 p. (in Russian) 
13. Yakutina M.V. (2002). Prosodicheskiye formy rechevogo povedeniya uchastnikov sudebnogo protsessa (eksperimental'no-foneticheskoye issledovaniye na materiale audiozapisey Verkhovnogo Suda SSHA): avtoref.... kand. filol. nauk [Prosodic forms of participants' speech behavior in a trial (an experimental phonetic study based on audio recordings of the US Supreme Court): abstract ... cand. philol. sciences]. Moskva, 22 p. (in Russian)

14. Yaskevich B.B. (2007). Vzaimodeystviye faktorov foneticheskogo var'irovaniya (v chtenii i spontannoy rechi vzroslykh i podrostkov v amerikanskom variante angliyskogo yazyka): avtoref. ... kand. filol. nauk [The interaction of factors of phonetic variation (in reading and spontaneous speech of adults and adolescents in American English): abstract ... cand. philol. sciences]. Minsk: Uchrezhdeniye «Minskiy Gosudarstvennyy Lingvisticheskiy Universitet», 20 p. (in Russian)

15. Crystal D. (1980). A First Dictionary of Linguistics and Phonetics. London: Andre Deutsch, $390 \mathrm{p}$. 